\title{
Genetic Diversity of Rhizophora Apiculata Blume in Banggai Kepulauan Inferred from Sequence-related Amplified Polymorphism (SRAP) Marker
}

\author{
Seni Kurnia Senjaya ${ }^{1 *}$ \\ ${ }^{1}$ Research Center for Biology, National Research and Innovation Agency, Cibinong Science Center, Indonesia \\ *Corresponding author. Email: senikurnia@gmail.com
}

\begin{abstract}
Mangroves are among the most productive and biologically important ecosystems in the world, providing many services that bridge processes in the ocean and land. One of the species of mangrove forest in the Banggai Kepulauan is Rhizophora apiculata Blume. Regional development and climate change pose a threat to the population of R. apiculata in that area. This study aims to get a better picture of the diversity and genetic structure of R. apiculata in the Banggai Kepulauan. A better understanding of its population genetics hopefully will serve as a guide for proper conservation management. This study was conducted using five SRAP primer pairs. The results of the analysis showed that the genetic diversity of $\mathrm{R}$. apiculata was relatively low $(\mathrm{He}=0.173+0.008)$. The population was grouped into two clusters with two populations on the central of Peleng island separated from other populations. Low genetic diversity could affect the long-term survival of the population. Human intervention is needed to reduce anthropogenic disturbances and further preserve the remaining R. apiculata population in the Banggai Kepulauan.
\end{abstract}

Keywords: mangrove, SRAP, Banggai.

\section{INTRODUCTION}

Indonesian waters are mostly included in the Central Indo-Pacific realm, which is divided into five provinces, namely Sunda Shelf, Java Transitional, Western Coral Triangle, and Sahul Shelf [1]. Western Sumatra ecoregion, also part of Indonesian waters, is part of the Western Indo-Pacific realm, Andaman province [1]. The waters of the Peleng and Bakalan island, Banggai Kepulauan district are part of the Western Coral Triangle province which has the most diverse coral reefs, mangroves, and seagrass beds in the world. One of the mangrove ecosystem species is Rhizophora apiculata Blume.

In the exploration conducted by the team of Research Center for Biology, Indonesian Institute of Sciences, it was found that $R$. apiculata was present in all mangrove populations along the central and eastern coasts of Peleng island and the west coast of Bakalan island. The population genetic structure of $R$. apiculata in Indonesia consists of three areas in the Sunda Shelf Mangrove region and one isolated area in the New
Guinean Mangrove region [2]. However, R. apiculata populations from the east coast of Sulawesi and islands in the Maluku Sea and the Banda Sea were not included in the study. Bakalan Island and Peleng Island in the east of Sulawesi, located between the Peleng strait and the Banda Sea, are the habitat of $R$. apiculata. Information regarding the genetic diversity and population structure of $R$. apiculata in the two islands is unknown.

More than half of the world's mangroves have been lost in the last 50 years due to natural and anthropogenic causes [3]. Anthropogenic threats also occur on Peleng Island, the administrative center of Banggai Kepulauan district which continues to be developed both as a government center and as a tourist destination. Territorial development means pressure on natural populations from anthropogenic disturbance. In addition, the threat of climate change can also greatly affect the mangrove population on Peleng and Bakalan islands. Increasing threats can cause mangrove ecosystems to become smaller and more fragmented. Therefore, a better understanding of genetic diversity 
and population genetic structure of mangrove species such as $R$. apiculata is essential for identifying vulnerable populations and appropriate management that can be done.

Genetic diversity and population genetic structure of $R$. apiculata in this study were analyzed using Sequence-related amplified polymorphism (SRAP) markers. SRAP markers belong to a targeted group of fingerprint markers. The markers are multilocus and produced semi-randomly and target multiple sequence regions in the genome [4].

\section{METHODS}

\subsection{Plant Sample}

A total of 49 individuals of $R$. apiculata was sampled from six natural populations along the coast of Banggai Kepulauan district: five populations in Peleng island and one population in Bakalan island (Figure 1). Leaf materials from 5 to 11 trees for each population were collected (Table 1) between June and July 2019. Medium aged, healthy leaves were cut into small pieces and stored in a tea bag before being placed in a zip-lock plastic bag filled with silica gel. Voucher specimens were also collected and stored at the Herbarium Bogoriense.

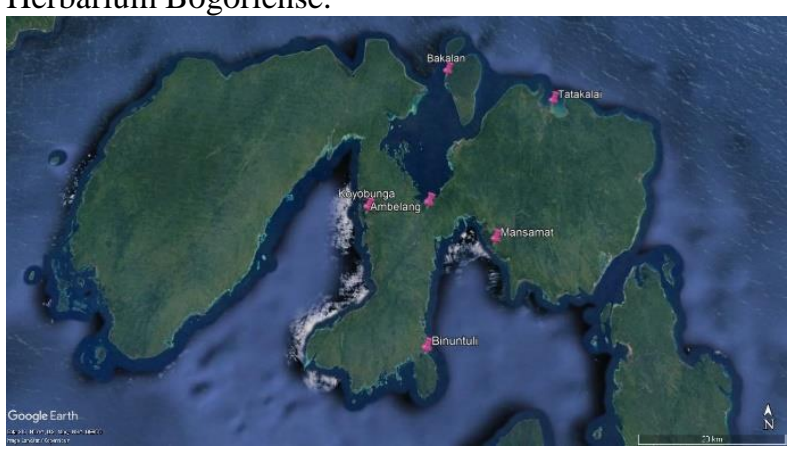

Figure 1. Sampling site of Rhizophora apiculata populations in Banggai Kepulauan.

Table 1. Genetic diversity of six Rhizophora apiculata populations

\begin{tabular}{|c|c|c|c|c|c|c|c|}
\hline Population & Locality & $\begin{array}{l}\text { Sam } \\
\text { ple } \\
\text { Size }\end{array}$ & $\mathrm{He}$ & I & PPL & Gst & $\begin{array}{l}\text { using STRUCTURE } 2.3 .4[8] \text {. Dataset was explored } \\
\text { Uming the admixture model, which can detect structure }\end{array}$ \\
\hline Tatakalai & Peleng & 8 & $0.138 \pm 0.019$ & $0.222 \pm 0.028$ & 51.43 & - & among populations that are potentially similar due \\
\hline Bakalan & Bakalan & 5 & $0.128 \pm 0.022$ & $0.194 \pm 0.032$ & 37.14 & & shared ancestry or migration, with a burn-in length \\
\hline Binuntuli & Peleng & 8 & $0.094 \pm 0.016$ & $0.158 \pm 0.025$ & 42.86 & - & 10,000 followed by 100,000 Markov Chain Mon \\
\hline Mansamat & Peleng & 7 & $0.191 \pm 0.020$ & $0.302 \pm 0.036$ & 67.14 & - & Carlo (MCMC) iterations. The optimum number of $\mathrm{K}$ \\
\hline Ambelang & Peleng & 11 & $0.142 \pm 0.022$ & $0.216 \pm 0.042$ & 45.71 & - & was calculated using the $\Delta \mathrm{K}$ method of [9]. \\
\hline Koyobunga & Peleng & 10 & $0.091 \pm 0.020$ & $0.140 \pm 0.037$ & 32.86 & - & Subsequently, each individual was assigned to eac \\
\hline Species level & & 49 & $0.173 \pm 0.014$ & $0.292 \pm 0.019$ & 97.14 & 0.274 & ning STRUCTURE with \\
\hline
\end{tabular}

He = Nei's gene diversity; I = Shannon's information index; PPL = percentage of polymorphic; GST = population differentiation value; $\mathrm{Nm}=$ estimated gene flow. Values are shown as mean $\pm \mathrm{SE}$

\subsection{DNA Isolation and Amplification}

Total DNA was isolated from the silica-dried leaves following the GeneAid Plant Genomic DNA Mini KIT (GeneAid) protocol. A total of 25 primer pairs resulting from the combination of 5 forward primers $(\mathrm{Me} 1, \mathrm{Me} 2, \mathrm{Me} 3, \mathrm{Me} 4, \mathrm{Me} 5)$ and 5 reverse primers (Em1, Em2, Em3, Em4, Em5) [5] were screened. The polymerase chain reaction (PCR) was performed in $15 \mu \mathrm{L}$ of reaction mixture containing 10 ng DNA template, $7.5 \mu \mathrm{L}$ GoTaq ${ }^{\circledR}$ Green Master Mix (Promega), and $2 \mu \mathrm{M}$ of both forward primer and reverse primer. The PCR program for amplification was set following [5] with pre-denaturation at $95^{\circ} \mathrm{C}$ for $5 \mathrm{~min}$, five cycles of denaturation at $95^{\circ} \mathrm{C}$ for $1 \mathrm{~min}$, annealing at $35^{\circ} \mathrm{C}$ for $1 \mathrm{~min}$ and extension at $72^{\circ} \mathrm{C}$ for 1 min followed by 35 cycles of denaturation at $95^{\circ} \mathrm{C}$ for $1 \mathrm{~min}$, annealing at $50^{\circ} \mathrm{C}$ for $1 \mathrm{~min}$ and extension at $72^{\circ} \mathrm{C}$ for $1 \mathrm{~min}$, ended by a final extension at $72^{\circ} \mathrm{C}$ for $5 \mathrm{~min}$. The PCR products were electrophoresed in $1.5 \%$ agarose gel for $90 \mathrm{~min}$ at $100 \mathrm{~V}$, and then visualized by the staining is using GelRed Nucleic Acid Gel Stain (Biotium)

\subsection{Data Analysis}

Bands produced in agarose gel were scored as 1 (present) or 0 (absent) manually and using the Image Lab 6.01 (Bio-Rad) software. Data were calculated using the POPGENE version 1.32 [6] software to calculate the percentage of polymorphic loci (PPL), Nei's genetic diversity (He), Shannon information index (I), and the genetic coefficient of differentiation (GST). We also analysed the levels of genetic differentiation in $R$. apiculata populations using were determined by GenAlEx 6.5 [7]. Gene flow among populations was estimated indirectly using the formula $\mathrm{Nm}=0.5$ (1-GST)/GST (Slatkin and Barton, 1989). To infer the populations' genetic structure, we applied a model-based Bayesian clustering method using STRUCTURE 2.3.4 [8]. Dataset was explored using the admixture model, which can detect structure among populations that are potentially similar due to Carlo (MCMC) iterations. The optimum number of $\mathrm{K}$ was calculated using the $\Delta \mathrm{K}$ method of [9]. optimum K value, burn-in length of 10,000 , and run Analysis of Molecular Variance (AMOVA) which 
length of 100,000 MCMC replications. Additionally, to complement population structure analysis, a UPGMA dendrogram was constructed based on population Nei and Li's distances using Mega X [10].

\section{RESULT AND DISCUSSION}

Based on the screening of the 25 SRAP primer combinations, five primer pairs produced polymorphic bands (Table 2). The primers produced 70 bands, of which $97.14 \%$ were polymorphic.

Table 2. Primer pairs and sequences

\begin{tabular}{cc}
\hline Primer pair & DNA sequence (5'-3') \\
\hline Me1/Em3 & TGAGTCCAAACCGGATA/GACTGCGTACGAATTGAC \\
Me4/Em3 & TGAGTCCAAACCGGACC/GACTGCGTACGAATTGAC \\
Me5/Em2 & TGAGTCCAAACCGGAAG/ GACTGCGTACGAATTTGC \\
Me5/Em3 & TGAGTCCAAACCGGAAG/ GACTGCGTACGAATTGAC \\
Me5/Em4 & TGAGTCCAAACCGGAAG/GACTGCGTACGAATTTGA \\
\hline
\end{tabular}

Within each population, He ranged from $0.091 \pm$ 0.020 to $0.191 \pm 0.020$, I ranged from $0.140 \pm 0.037$ to $0.302 \pm 0.036$ (from the lowest to the highest) and PPL ranged from $32.86 \%$ to $67.14 \%$ (Table 1). The highest and the lowest genetic diversity were observed in the Mansamat $(\mathrm{He}=0.191 \pm 0.020)$ and Koyobunga $(\mathrm{He}=0.091 \pm 0.020)$ populations, respectively. At the species level, He is $0.173 \pm 0.014$ and $\mathrm{I}$ is $0.292 \pm 0.019$. The genetic diversity of $R$. apiculata in the Banggai Kepulauan district was relatively low. Low genetic diversity was also observed in $R$. apiculata population in the Greater Sunda Islands $(\mathrm{He}=0.378+0.014)[2]$, North Sulawesi $(\mathrm{He}=0.451 \pm 0.083)$, Tarakan $(0.447$ $\pm 0.068)$ [11], and Peninsular Malaysia $(\mathrm{He}=0.352)$ [12]. The proportion of genetic variation distributed among populations (GST) was estimated at 0.274, indicating $72.6 \%$ of the total genetic variability was distributed within the population. The level of gene flow (Nm) among populations was estimated to be 1.325. AMOVA analysis (Table 3) showed significant and high variation within populations $(\mathrm{p}<0.001)$. A total of $77 \%$ of the variation was distributed within populations and $23 \%$ of the total variation was partitioned among populations.

Table 3. Analysis of molecular variance of 6 populations of Rhizophora apiculata

\begin{tabular}{cccccc}
\hline $\begin{array}{l}\text { Source of } \\
\text { variation }\end{array}$ & df & SS & MS & Est. Var. & $\%$ \\
\hline Among Pops & 5 & 147,259 & 29,452 & 2,578 & $23 \%$ \\
Within Pops & 43 & 371,517 & 8,640 & 8,640 & $77 \%$ \\
Total & 48 & 518,776 & & 11,218 & $100 \%$ \\
df = degrees of freedom; & SS = sums of squares; MS = mean squares
\end{tabular}

The Bayesian approach was used to analyse the population structure and the results showed that $R$. apiculata in Banggai Kepulauan consist of two clusters (Figure 2). One cluster (green) consists of individuals originated from Tatakalai, Bakalan, Mansamat, and Binuntuli. Meanwhile, another cluster (red) consists of individuals that originated from Koyobunga and Ambelang (Figure 3). UPGMA tree was constructed based on population genetic distance. The analysis resulted in a dendrogram with two clades. Clades from UPGMA were congruent with clusters produced using STRUCTURE. Based on UPGMA dendogram, clade I consists of Tatakalai, Bakalan, Mansamat and Bintuntuli populations. Meanwhile, clade II consists of Koyobunga and Ambelang populations (Figure 4).

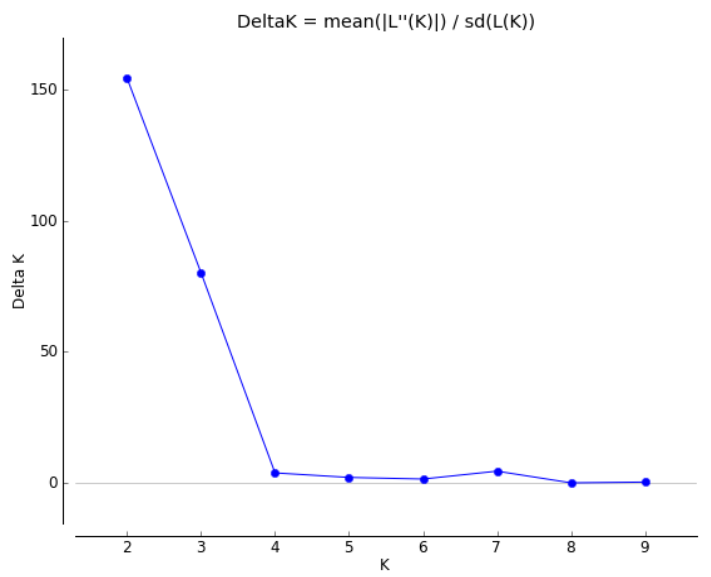

Figure 2. Structure estimation number of clusters for $\mathrm{K}$ values ranging from 1 to 10 , based on delta $\mathrm{K}$ values

Genetic diversity is influenced by several factors. Important factors that are often considered to influence the level of genetic diversity are evolutionary history, biological traits, and mating systems. Outcrossing species usually have a much higher level of genetic diversity than selfing species [13]. Rhizophora species are self-compatible and predominantly windpollinated [14]. The breeding system of $R$. apiculata can be defined as mixed mating or predominantly outcrossing [11]. However, the mating system is not the only factor that shapes the genetic diversity of $R$. apiculata. Genetic diversity in mangroves is also -strongly influenced by pollination and propagules dispersal. Mangrove distribution is a combination of aquatic and terrestrial processes in which propagules are dispersed by sea currents and pollination occurs with the help of insects [15]. While pollination by insects is generally intrapopulation, light mangrove propagules remain viable in the water for long periods. 
Therefore, they have the potential to be carried by ocean currents to other populations [16]. This propagule distribution allows for gene flow from one population to another and is therefore expected to result in a high level of population connectivity and a small genetic structure over long distances.

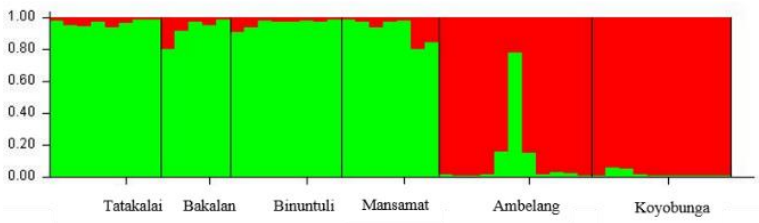

Figure 3. Population structure of 49 Rhizophora apiculata individuals for $\mathrm{K}=2$ with 10 iterations and a burn-in length of 10,000 and a run length of 100,000 Markov Chain Monte Carlo replications

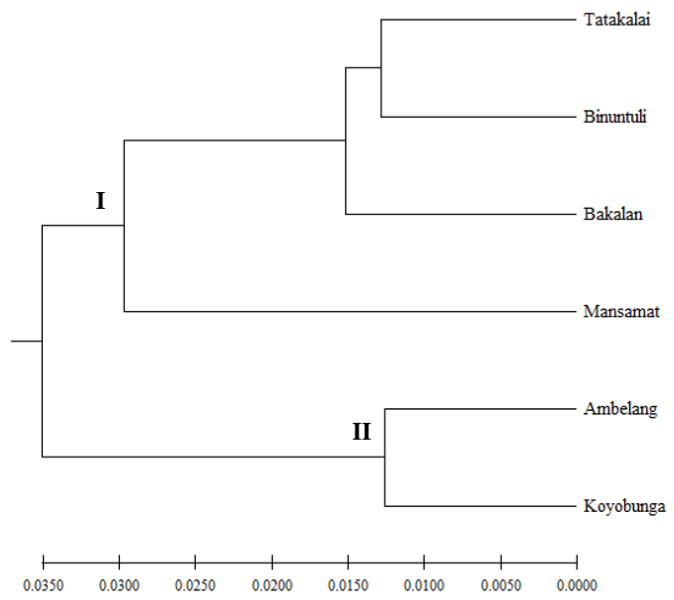

Figure 4. Unweighted pair-group method of averages dendrogram of Rhizophora apiculata populations based on Nei's and Li's genetic distance

The estimated gene flow $(\mathrm{Nm})$ of $R$. apiculata in the Banggai Kepulauan is 1.32. The Nm value of more than 1 means there is enough gene flow to negate the effects of genetic drift [17]. Even though the estimated gene flow is high, structuring occurred in R. apiculata in Banggai Kepulauan which are divided into two clusters and the most variation occurs within the population. Two separate populations, Ambelang and Koyobunga are located on the central of Peleng island. The separate cluster could indicate the species has a different ancestral or from the same ancestral but is isolated due to the existence of barriers. We suspect the dysconnectivity between the two clusters might be due to barriers such as ocean circulations, wind, large distances, longevity, and land barriers. However, in this study we were unable to identify the exact reason for structuring. Other studies have shown that mangrove propagules tend not to spread too far from their point of release. A study in the Avicenna marina has shown that propagule distribution is spatially limited and the presence of a significant deficiency in propagule distribution presents a strong barrier to gene flow [18]. The Central American Isthmus acts as a very strong barrier to gene flow in populations of $R$. mangle and A. germinans on the Caribbean and Pacific coasts of Panama [19].

\section{CONCLUSION}

Given that populations with a lack of genetic diversity often exhibit a greater risk of extinction, the low genetic diversity of $R$. apiculata in Banggai Kepulauan may reduce its fitness and affect its longterm survival. As anthropogenic disturbances continue to occur, the survival of the population is threatened. Populations with high genetic diversity deserve high priority for conservation but other populations must also be protected considering their ecological functions as a habitat for other organisms.

\section{ACKNOWLEDGMENT}

This research is part of the Biological Resource Management for the Outermost Small Island Project funded by the Research Center for Biology - LIPI. We would like to thank the Banggai Kepulauan Regency Government and the Banggai Kepulauan Environmental Service for all their assistance during field activities. We also thank the Plant Ecology research team (Kusuma Rahmawati and M. Syarifudin Hidayatullah) who have played a role in sample collection.

\section{REFERENCES}

[1] M. D. Spalding et al., "Marine Ecoregions of the World : A Bioregionalization of Coastal and Shelf Areas," Bioscience, vol. 57, no. 7, pp. 573-583, 2007.

[2] A. F. Yahya et al., "Genetic variation and population genetic structure of Rhizophora apiculata (Rhizophoraceae) in the Greater Sunda Islands, Indonesia using microsatellite markers," J Plant Res, vol. 127, pp. 287-297, 2014, doi: 10.1007/s10265-013-0613-z.

[3] C. Giri et al., "Status and distribution of mangrove forests of the world using earth observation 
satellite data," Glob. Ecol. Biogeogr., vol. 20, no. 1, pp. 154-159, 2011, doi: 10.1111/j.14668238.2010.00584.x.

[4] P. Poczai, I. Varga, A. Cseh, N. Bell, J. P. T. Valkonen, and J. Hyvönen, "Advances in plant gene-targeted and functional markers : a review," Plant Methods, vol. 9, p. 6, 2013, doi: 10.1186/1746-4811-9-6.

[5] G. Li and C. F. Quiros, "Sequence-related amplified polymorphism (SRAP), a new marker system based on a simple PCR reaction: Its application to mapping and gene tagging in Brassica,” Theor. Appl. Genet., vol. 103, pp. 455461, 2001, doi: 10.1007/s001220100570.

[6] F. Yeh, R. Yang, T. Boyle, Z. Ye, and J. Mao, "POPGENE version 1.31: the user-friendly software for population genetic analysis." University of Alberta, Alberta, Canada, 1999, [Online]. Available: https://sites.ualberta.ca/ fyeh/popgene.html.

[7] R. Peakall and P. E. Smouse, "GenALEx 6.5: genetic analysis in excel. population genetic software for teaching and research-an update," Bioinformatics, vol. 28, no. 19, pp. 2537-2539, 2012, doi: 10.1093/bioinformatics/bts460.

[8] J. K. Pritchard, Documentation for structure software : Version 2 . 3. 2010.

[9] D. A. Earl, S. Cruz, and B. M. Vonholdt, "Structure Harvester : a website and program for visualizing STRUCTURE output and implementing the Evanno method," Conserv. Genet. Resour., vol. 4, pp. 359-361, 2012, doi: 10.1007/s12686-011-9548-7.

[10] S. Kumar, G. Stecher, M. Li, C. Knyaz, and K. Tamura, "MEGA X: Molecular evolutionary genetics analysis across computing platforms," Mol. Biol. Evol., vol. 35, no. 6, pp. 1547-1549, 2018, doi: 10.1093/molbev/msy096.

[11] Y. Yan, N. C. Duke, M. Sun, and M. Sun, "Comparative analysis of the pattern of population genetic diversity in three Indo-West Pacific Rhizophora mangrove species," Front.
Plant Sci., vol. 7, p. 1434, 2016, doi: 10.3389/fpls.2016.01434.

[12] A. Azman et al., "Low genetic diversity indicating the threatened status of Rhizophora apiculata (Rhizophoraceae) in Malaysia: declined evolution meets habitat destruction," Sci. Rep., vol. 10, no. 1, pp. 1-12, 2020, doi: 10.1038/s41598-02076092-4.

[13] J. L. Hamrick and M. J. W. Godt, "Effects of life history traits on genetic diversity in plant species," Philos. Trans. R. Soc. London B, vol. 351, pp. 1291-1298, 1996.

[14] T. L. Nadia and I. C. Machado, "Wind pollination and propagule formation in Rhizophora mangle L. (Rhizophoraceae): resource or pollination limitation?," An. Acad. Bras. Cienc., vol. 86, no. 1, pp. 229-238, 2014, doi: 10.1590/000137652014101712 .

[15] A. E. Lugo and S. C. Snedaker, "The Ecology of Mangroves," Annu. Rev. Ecol. Syst., vol. 5, no. 1, pp. 39-64, 1974, doi: 10.1146/annurev.es.05.110174.000351.

[16] P. B. Tomlinson, The botany of mangroves, 2nd ed. New York: Cambridge University Press, 1986.

[17] S. Wright, "Evolution in mendelian populations," Genetics, vol. 16, no. 2, pp. 97-159, 1931.

[18] R. M. Binks, M. Byrne, K. McMahon, G. Pitt, K. Murray, and R. D. Evans, "Habitat discontinuities form strong barriers to gene flow among mangrove populations, despite the capacity for long-distance dispersal," Divers. Distrib., vol. 25, no. 2, pp. 298-309, 2019, doi: 10.1111/ddi.12851.

[19] I. Cerón-Souza, E. Bermingham, W. O. McMillan, and F. A. Jones, "Comparative genetic structure of two mangrove species in Caribbean and Pacific estuaries of Panama," BMC Evol. Biol., vol. 12, p. 205, 2012, doi: 10.1186/14712148-12-205. 